BISMA

(Bisnis dan Manajemen)
Volume 10, Nomor 2, April 2018, 145-155

ISSN 2549-7790 (Online)

ISSN 1979-7192 (Print)

https://journal.unesa.ac.id/index.php/bisma/index

\title{
FAKTOR KREATIVITAS DALAM PENGEMBANGAN MODEL INKUBATOR BISNIS DI ERA DIGITAL
}

\author{
Anna Pudianti ${ }^{1}$, Anita Herawati ${ }^{2}$, Anna Purwaningsih ${ }^{3}$ \\ Universitas Atma Jaya Yogyakarta ${ }^{1,2,3}$ \\ Email korespondensi: pudiantianna2014@gmail.com
}

\begin{abstract}
A business incubator is a program to encourage the emergence of student's entrepreneurs in various universities, including Universitas Atma Jaya Yogyakarta. The model applied in generating new entrepreneurs through business incubators at Universitas Atma Jaya Yogyakarta is described in three (3) stages of pre-incubation, incubation, and post-incubation. In the third stage of the incubation process, post incubation, the students have been assessed their readiness before finally tenant plunge as an entrepreneur. In the previous study, the motivation or desire to become an entrepreneur is a major factor to support success in business. However, in the next stage to support business sustainability, especially in the digital era as it is today, the strong capital motivation is not enough. This study aims to examine more deeply the capabilities that must be built to support business sustainability, especially in the digital age with all the technological advances. The qualitative approach is used by using successful tenants as case studies of several types of business, in order to enrich the results of the research. Triangulation and member check processes are applied to generate the results of the research. The resulting model of this study is a refinement of the initial model by emphasizing the sustainability factor of business in the digital era that emphasizes the importance of creative ability and thinking ahead.
\end{abstract}

Keywords: entrepreneurship, student entrepreneurship model, creativity, business incubator

Received: 7 Maret 2018

Reviewed: 5 April 2018

Accepted: 24 April 2018

Published: 26 April 2018

\section{PENDAHULUAN}

Berbagai program pemerintah dalam beberapa tahun terakhir telah digulirkan untuk meningkatkan jumlah wirausahawan di Indonesia. Pada tahuan 2016 saja terdapat tiga produk hukum yang bertujuan untuk memajukan dan menciptakan wirausaha baru (Kementrian Koperasi dan Usaha Kecil dan Menengah Republik Indonesia, 2017) yaitu Keputusan Menteri Koperasi dan Usaha Kecil dan Menengah 
Nomor 33/Kep/M.KUKM/XII/2016 Tentang Penetapan Perogram Bantuan Dana Bagi Koperasi Pemula dan Program Bantuan Dana Bagi Wirausaha Pemula Sebagai Bantuan Lainnya yang Memiliki Karakteristik Bantuan Pemerintah di Lingkungan Deputi Bidang Pembiayaan, Kementrian Koperasi dan Usaha Kecil dan Menengah; Peraturan Menteri Koperasi dan Usaha Kecil dan Menengah Republik Indonesia Nomor 18/Per/M.KUKM/XII/2016 Tentang Pedoman Umum Penyelenggaraan Bantuan Pemerintah Pada Kementrian Koperasi dan Usaha Kecil dan Menengah; dan Peraturan Deputi Bidang Pembiayaan Kementrian Koperasi dan Usaha Kecil dan Menengah Nomor 08/Per/ Dep.2/XI/2016 Tentang Petunjuk Teknis Pelaksanaan Bantuan Pemerintah Bagi Wirausaha Pemula. Produk hukum tersebut hanya salah satu contoh terkini yang menegaskan keseriusan pemerintah untuk meningkatkan jumlah wirausaha di Indonesia.

Perguruan tinggi di Indonesia pun telah ikut serta dalam mempersiapkan tenaga kerja yang berorientasi pada menciptakan lapangan kerja daripada hanya sebagai pencari kerja. Berbagai skema dikembangkan pula oleh Kementrian Riset Teknologi dan Pendidikan Tinggi untuk mendorong percepatan tercapainya target pemerintah untuk menciptakan 5000 wirausaha baru dan 1200 sentra industri di tahun 2017 dan 20.000 wirausaha baru di tahun 2019 (Kompas,Pramdia). Inkubator bisnis adalah salah satu program yang dirancang untuk membantu penciptaan wirausaha di kalangan mahasiswa (tenant). Cara yang digunakan adalah dengan melalui serangkaian proses belajar berbisnis melalui pendampingan, kemitraan dengan pebisnis yang telah berhasil menjalankan usaha agar calon wirausaha baru dapat mempelajari pengalaman kegagalan dan keberhasilan perjalanan usaha (Purwaningsih, Herawati, Pudianti, \& Septiari, 2017).

Universitas Atma Jaya Yogyakarta (UAJY) di bawah Pusat Studi Kewirausahaan (PUSWIRA) juga telah mengadopsi program inkubator bisnis melalui skema Ipteks Bagi Kewirausahaan (IbK) yang dibiayai oleh Ristekdikti. Program ini telah memasuki tahun ketiga. Tahun pertama penekanan program diwarnai dengan pembentukan model inkubator bisnis. Pada tahun ke dua telah disusun sebuah Model Wirausaha Mahasiswa melalui Inkubator Bisnis. Pada tahun ketiga atau tahun terakhir skema, penekanan pada penyempurnaan model inkubator bisnis dengan pengembangan sistem informasi.

Pengembangan sistem informasi pada tahun ketiga juga dilandasi isu era bisnis digital. Menurut (Kasali, 2017), di era digital para pengusaha perlu menyadari kehadiran pengganggu atau penghalang digital (digital discruption). Kehadiran teknologi digital dapat berdampak pada matinya bisnis model lama yang masih mengandalkan fisik. Menanggapi pengganggu digital bisnis di era digital ini, proses inkubator bisnis di UAJY tahun ketiga ini selain memasukkan materi bisnis online dan pembuatan sistem informasi bagi wirausaha baru di UAJY yang menekankan 
pada penggunaan digital dan salah satu solusi menghadapi era digital ini yaitu faktor kreativitas.

Kreativitas memang bukan hal baru dalam kewirausahaan. Hampir semua referensi kewirausahaan memasukkan kreativitas sebagai faktor yang perlu mendapat perhatian. Akan tetapi, muncul pertanyaan yang menjadi pertanyaan penelitian yaitu "bagaimana kreativitas dikembangkan pada era digital". Hal ini belum banyak dikaji. Menurut Lubart (2001), proses kreatif perlu selalu diperbaharui sesuai perkembangan terbaru masa mendatang. Digital era pada masa kinipun merupakan suatu perubahan yang sangat signifikan dalam mempengaruhi model kreativitas. Terkait dengan era digital saat ini, pertanyaan pertama yang memicu pertanyaan lanjutan yaitu "mengapa proses kreativitas berubah dengan setelah memasuki era digital dan bagaimanakah perubahan proses tersebut terjadi. Oleh karena itu tujuan penelitian ini untuk memperkaya dan mengevaluasi modul pembekalan yang telah diterapkan bagi wirausaha pemula melalui program inkubator bisnis di UAJY, terutama difokuskan untuk mengeksplorasi lebih dalam kemampuan berkreasi yang harus dibangun untuk mendukung keberlanjutan bisnis, terutama di era digital dengan semua kemajuan teknologi.

Studi yang telah dilakukan sebelumnya pada tahun pertama dan kedua pelaksanaan program Inkubator Bisnis di UAJY menekankan pada hal yang berbeda. Pada tahun pertama penelitian di fokuskan pada evaluasi program inkubator bisnis di UAJY secara keseluruhan (Herawati, Septiari, Purwaninsgih, \& Pudianti, 2016), sedangkan pada tahun ke dua kajian ditekankan pada penyusunan model inkubator bisnis untuk bisnis mahasiswa (Purwaningsih, Herawati, Pudianti, \& Septiari, 2017). Pada tahun ketiga ini fokus kajian adalah menyempurnakan model inkubator bisnis pada tahun kedua dengan menekankan tinjauan pada kreativitas di era digital. Kajian tentang model wirausaha mahasiswa yang pernah dilakukan meliputi program kewirausahaan mahasiswa secara terpadu yang meliputi berbagai program kewirausahaan yang ada di universitas (Murwaningsih, 2015). Sedangkan studi terdahulu tentang kreativitas dan inovasi ditekankan pada kewirausahaan usaha kecil secara umum (Hardiyati, 2011) dan kreativitas dan inovasi pada wirausaha pemula (Baldacchino, 2009). Kebaruan penelitian ini adalah pada isu kreativitas di era digital yang cepat berubah. Perubahan yang cepat merupakan salah satu penyebab stres di kalangan wirausaha, terlebih lagi jika tidak didukung adanya komunikasi yang baik dan kemampuan untuk mengendalikan sumber daya yang ada (Hizam \& Khairuddin, 2015). Oleh karena itu sangat penting isu penelitian ini diangkat agar dapat mengantisipasi kondisi stres bagi wirausaha pemula dalam memasuki era digital. 


\section{METODE PENELITIAN}

Penelitian ini menggunakan pendekatan kualitatif dengan strategi penelitian studi kasus (Yin, 2013). Strategi penelitian studi kasus digunakan dengan mengacu pada pernyataan Yin yang mengatakan bahwa studi kasus sangat tepat digunakan untuk menjawab pertanyaan "bagaimana (how)" dan "mengapa (why)". Selain itu studi kasus merupakan perpaduan metode induktif dan debuktif yang sangat sesuai untuk mengkaji ilmu-ilmu sosial ataupun analisis dokumenter seperti dalam studi ekonomi. Dalam studi kasus, teori yang digunakan membentuk proposisi yang diyakini kebenarannya, namun untuk mengembangkan teori perlu dipilih studi kasus yang dapat digunakan menguji proposisi tersebut (Yin, 2013).

Penelitian studi kasus ini terbatas pada kasus yang ada pada pelaksanaan program Ipteks bagi Kewirausahaan (IbK) di Universitas Atma Jaya Yogyakarta yang telah memasuki pelaksanaan tahun ke tiga, sehingga dapat melihat kecenderungan keberlanjutan usaha dari tahun yang terbaru (tahun pertama) hingga tahun yang terlama (tiga tahun). Proposisi yang menjadi fokus penelitian ini adalah di era digital tenant perlu mendapatkan materi terkait dengan diskrupsi atau gangguan digital. Untuk memperkaya pembahasan studi kasus, maka pemilihan studi kasus menggunakan kriteria wirausaha yang memiliki konsistensi keberlanjutan usaha, berasal dari kelompok bisnis variasi jenis usaha berbeda, skala pasar, serta variasi penggunaan media digital.

Dalam studi kasus inkubator bisnis Universitas Atma Jaya Yogyakarta yang telah berjalan tiga tahun, terdapat berbagai jenis usaha yang berbeda, sehingga kelompok jenis usaha diambil agar dapat menggambatkan kondisi riil di lapangan. Mengingat waktu pelaksanaan program adalah tiga tahun maka akan terdapat tiga karakter berbeda menurut lama menjalankan usaha. Kemudian juga pemilihan jenis usaha diupayakan agar dapat mewakili jenis usaha yang berbeda dengan menggambil praktek terbaik untuk setiap tahun dari berbagai jenis usaha. Melihat kriteria tersebut, maka terpilih enam studi kasus. Tahun pertama meliputi dua studi kasus kategori kuliner yang walaupun masuk kategori yang sama namun memiliki perbedaan bentuk produk yaitu produk bahan baku kuliner padat dan minuman susu cair kemasan. Tahun ke dua meliputi bisnis kerajinan tas dan tempat pensil dan jasa jual beli mobil online. Tahun ke tiga meliputi produk kosmetik dan fashion. Masing-masing kasus merupakan praktek terbaik di bidangnya pada setiap peiode waktu.

Pembatasan studi kasus dilakukan agar dapat memberikan pembahasan secara lebih mendalam pada masing-masing kasus serta memberikan hasil yang relevan bagi keberagaman jenis usaha. Teknik pengumpulan data dengan triangulasi dan member check digunakan untuk memperkuat validasi data. Data diperoleh melalui wawancara mendalam dan pengamatan langsung. Hasil proses observasi dan wawancara mendalam ini digunakan untuk menyempurnakan model inkubator bisnis 


\section{HASIL DAN PEMBAHASAN}

Inkubator bisnis di UAJY telah berjalan selama hampir tiga tahun. Jumlah usaha siswa (tenant) yang dipantau adalah 20 tenant pada tahun pertama (Herawati, Purwaningsih, \& Pudianti, 2015) dan 16 tenant pada tahun ke dua (Herawati, Purwaningsih, \& Pudianti, 2016), dan 16 tenant pada tahun ke tiga (Herawati, Purwaningsih, \& Pudianti, 2017). Pada tahun pertama, 9 tenant dinyatakan mandiri dan siap bersaing dengan pengusaha lain di luar kampus. Sementara 11 siswa masih membutuhkan bantuan. Target bisnis mandiri adalah 5 (25\%), tapi faktanya, di tahun pertama, target mencapai 45\%. Tahun kedua, jumlah bisnis siswa adalah 16, dua di antaranya berasal dari tahun pertama. Pada akhir tahun kedua, semua bisnis dinyatakan mandiri. Dengan demikian, tahun kedua melampaui target sebesar $25 \%$. Tahun ketiga masih dalam proses inkubator, akan tetapi dari 16 tenant ada 11 tenant atau $69 \%$ yang menonjol dalam hal kesiapan dan keberlanjutan usaha.

Inkubator bisnis adalah salah satu program yang dirancang untuk membantu penciptaan wirausaha di kalangan mahasiswa (tenant), namun keberlanjutan usaha yang telah terbentuk melalui proses ini perlu dipantau hambatan usaha dan cara tenant untuk mempertahankan keberlanjutannya. Dalam proses perkembangan usaha, lembaga inkubator bisnis berperan sebagai mitra dalam mencari penyelesaian masalah atau mencari jalan keluar dari hambatan yang dihadapi tenant agar usaha dapat terus berlanjut dan bahkan berkembang. Oleh karena itu peran lembaga dalam menciptakan wirausaha tidak berhenti hanya dalam tahap awal pembentukkan wirausaha, namun juga dalam memantau keberlanjutan usaha hingga mandiri. Dan dari hasil Inkubator Bisnis di Universitas Atma Jaya Yogyakarta dari tahun pertama hingga kedua memang menunjukkan peningkatan dalam hal kesiapan tenant walaupun terjadi secara dinamis, jumlah peningkatan dan besarnya.

Bidang usaha yang dikembangkan dari tahun pertama hingga ketiga adalah meliputi kuliner, kerajinan daur ulang limbah, fashion, aneka kerajinan tangan, jasa, budidaya jamur, kosmetik dan peternakan. Nilai ekonomi produk tenant cenderung memiliki nilai saing dibanding barang sejenis di pasaran karena inovasi dan kreativitas terkait dengan disiplin ilmu mereka (knowledge based). Tenant lebih berani mencoba sesuatu yang baru dengan memodifikasi produk yang sudah ada untuk menghasilkan barang yang lebih unik. Nilai ekonomi produk juga meningkat dengan memilih sarana distribusi atau pemasaran yang tepat baik pemasaran online, maupun pemasaran tradisional melalui jaringan pribadi, komunitas hobi dan toko atau showroom serta partisipasi dalam pameran produk. Pemasaran online mempengaruhi penghematan modal kerja, namun kenyataan tidak semua jenis usaha sesuai dipasarkan secara online. Produk yang tidak sesuai menggunakan pemasaran online atau menggunakan pemasaran online secara terbatas contohnya adalah produk susu 
kemasan, makanan basah yang memiliki keterbatasan masa kadaluwarsa. Contoh lain yaitu budidaya jamur, peternakan lele dan bebek memiliki keterbatasan produksi dan pasar lokal, sehingga tidak dapat secara keseluruhan menggunakan model distribusi atau pemasaran online.

Diakui tenant bahwa penggunaan media digital sebagai media pemasaran cukup efektif sehingga dapat dilakukan penghematan modal kerja agar harga jual lebih kompetitif, namun ada beberapa jenis produk yang memang hanya bermain pada pasar lokal atau juga karena keterbatasan produksi yang memaksa tenant untuk tidak menggunakan media digital secara menyeluruh. Pilihan tidak menggunakan media digital tersebut secara sadar dilakukan tenant agar tidak memberi citra buruk apabila mereka belum dapat memenuhi pesanan pelanggan melalui media digital. Ada pula tenant yang memilih untuk membatasi diri sebagai pemasok satu pelanggan besar dengan model kerjasama eksklusif yang menguntungkan kedua belah pihak.

Penggunaan media digital pada tenant tidak terbatas hanya pada media pemasaran, akan tetapi juga digunakan sebagai media pembelajaran pengembangan produk. Dalam wawancara terungkap bahwa media digital justru menjadi sumber inspirasi bagi pengembangan produk, terutama pada produk kreatif atau pengembangan bahan alternatif produk. Dengan melihat produk lain melalui media digital, kreasi produk tenant dapat lebih bervariasi dengan mengembangkan produk pembeda dari produk pesaing. Akan tetapi tenant juga menyadari akan tantangan penggunaan media digital sebagai media pemasaran yaitu produk merekapun sangat mungkin ditiru dan menjadi inspirasi bagi produk pesaing. Secara lengkap hasil wawancara terhadap tenant yang secara mandiri telah berhasil menjalankan bisnis secara berkelanjutan dapat dilihat pada tabel 1 .

Kreativitas dalam mencari solusi menghadapi persaingan ada beberapa macam, ada produk yang menggunakan kemampuan kekhasan ketrampilan tangan (handmade), ada pula yang menekankan pada ciri khas produk agar tidak mudah ditiru pesaing, dan cara lain adalah secara rutin memproduksi disain baru agar dapat menjadi pelopor disain di dalam bidangnya. Cara menjadikan produk sebagai pelopor disain ,dengan konsekuensi secara rutin menciptakan produk baru pada periode tertentu, selaras dengan apa yang dikatakan pakar perubahan (Kasali, Discruption, 2017), bahwa telah terjadi perubahan radikal terhadap model bisnis tradisional sehingga banyak bisnis mengadopsi strategi untuk memenuhi kebutuhan pelanggan dengan cara meningkatkan pengalaman pelanggan.

Sternberg (2006) mengklasifikasikan kreativitas menjadi delapan tipe kreativitas berdasarkan daya penggerak kreativitas. Delapan tipe kreativitas tersebut dikelompokkan lagi menjadi 3 kelompok. Tipe pertama adalah tipe kreativitas yang menerima paradigma masa kini dengan upaya pengembangan terdiri dari empat subtipe kreativitas yaitu tipe replikasi, tipe redefinisi, tipe peningkatan ke depan, dan 
tipe peningkatan percepatan peningkatan. Tipe kedua adalah tipe kreativitas yang menolak paradigma saat ini dan berupaya menggantikan posisinya terdiri dari tiga sub tipe yaitu tipe pengubah arah, tipe rekonstruksi, dan tipe inisiasi ulang. Dan ketiga yaitu tipe kreativitas yang mensintesakan paradigma saat ini dengan satu sub tipe yaitu tipe integrasi. Dengan menggunakan model kreativitas yang dikembangkan Sternberg (2006) proses kreatif yang dialami tenant ada beberapa sub tipe seperti terlihat pada tabel 2 .

Tabel 1. Penggunaan Media Digital oleh UKM

\begin{tabular}{|c|c|c|c|c|c|}
\hline \multirow[b]{2}{*}{ Batch } & \multirow[b]{2}{*}{ Nama Bisnis } & \multirow[b]{2}{*}{$\begin{array}{l}\text { Kelompok } \\
\text { Bisnis }\end{array}$} & \multicolumn{2}{|c|}{ Penggunaan Media Digital } & \multirow[b]{2}{*}{$\begin{array}{l}\text { Skala } \\
\text { Pasar }\end{array}$} \\
\hline & & & Media Pemasaran & $\begin{array}{c}\text { Media Kreativitas } \\
\text { Produk }\end{array}$ & \\
\hline \multirow[t]{2}{*}{ IbK 1} & $\begin{array}{l}\text { Budidaya } \\
\text { Jamur Tiram }\end{array}$ & $\begin{array}{l}\text { Kuliner } \\
\text { basah }\end{array}$ & $\begin{array}{l}\text { Belum menggunakan media } \\
\text { digital, karena keterbatasan } \\
\text { kapasitas produksi dan belum } \\
\text { mengembangkan metode } \\
\text { pengawetan dan kemasan. Masih } \\
\text { mengandal-kan posisi sebagai } \\
\text { pemasok tetap konsumen tertentu }\end{array}$ & Cara budidaya & Lokal \\
\hline & $\begin{array}{l}\text { Susu } \\
\text { Kemasan }\end{array}$ & $\begin{array}{l}\text { Kuliner } \\
\text { basah }\end{array}$ & $\begin{array}{l}\text { Belum menggunakan media } \\
\text { digital, karena keterbatasan } \\
\text { kapasitas produksi dan } \\
\text { keterbatasan keawetan produk }\end{array}$ & $\begin{array}{l}\text { Keunikan nama } \\
\text { produk dan kajian } \\
\text { produk pesaing }\end{array}$ & Lokal \\
\hline \multirow[t]{2}{*}{$\mathrm{IbK} 2$} & $\begin{array}{l}\text { Aneka tas } \\
\text { dan dompet } \\
\text { kain }\end{array}$ & Kerajinan & $\begin{array}{l}50 \% \text { menggunakan media digital, } \\
50 \% \text { jaringan personal. } \\
\text { Keterbatasan kapasitas produksi. }\end{array}$ & $\begin{array}{l}\text { Kreativitas desain } \\
\text { bentuk dan motif. } \\
\text { Kajian disain } \\
\text { pesaing }\end{array}$ & Nasional \\
\hline & $\begin{array}{l}\text { Jual beli } \\
\text { mobil }\end{array}$ & Jasa & $\begin{array}{l}\text { Menggunakan media online secara } \\
\text { keseluruhan, memberi kemudahan } \\
\text { konsumen }\end{array}$ & $\begin{array}{l}\text { Kreativitas } \\
\text { tampilan } \\
\text { advertising }\end{array}$ & Lokal \\
\hline \multirow[t]{2}{*}{ IbK 3} & $\begin{array}{l}\text { Kaos dan } \\
\text { mechandice } \\
\text { basket }\end{array}$ & Fashion & $\begin{array}{l}50 \% \text { jaringan pertemanan, } 25 \% \\
\text { penggunaan media digital, } 25 \% \\
\text { pameran produk \& showroom. }\end{array}$ & $\begin{array}{l}\text { Kreativitas desain } \\
\text { bentuk dan motif. } \\
\text { Kajian disain } \\
\text { pesaing }\end{array}$ & Nasional \\
\hline & $\begin{array}{l}\text { Penumbuh } \\
\text { bulu mata }\end{array}$ & Kosmetik & $\begin{array}{l}\text { Menggunakan media online secara } \\
\text { keseluruhan, memberi kemudahan } \\
\text { konsumen }\end{array}$ & $\begin{array}{l}\text { Kajian bahan baku } \\
\text { produksi }\end{array}$ & Nasional \\
\hline
\end{tabular}

Sumber: Analisis penulis, 2017

Dari analisis tipe kreativitas yang dipicu oleh adanya perkembangan media digital (diskrupsi digital) terlihat ada empat sub tipe kreativitas yang merupakan tiga pilar tipe kreativitas yaitu pilar pertama tipe kreativitas yang menerima paradigma masa kini dengan upaya pengembangan terdiri dengan sub tipe replikasi dan sub tipe peningkatan ke depan, pilar ke dua tipe kreativitas yang menolak paradigma saat ini dan berupaya menggantikan posisi dengan sub tipe tipe pengubah arah, dan pilar ke 
tiga yaitu tipe kreativitas yang mensintesakan paradigma saat ini dengan satu sub tipe yaitu tipe integrasi. Sub tipe dasar yaitu sub tipe replikasi dan sub tipe peningkatan ke depan ternyata banyak diaplikasikan oleh tenant pada inkubator bisnis tahun pertama bisnis mereka berjalan, sedangkan sub tipe yang lain diterapkan pada tahun kedua dan ketiga bisnis mereka berjalan dan mereka menyadari akan pentingnya penggunaan teknologi informasi sebagai alat bantu kreativitas bisnis. Jadi jelaslah bahwa diskrupsi digital bukan merupakan penghalang berkembangnya bisnis, akan tetapi justru memicu tumbuhnya kreativitas.

Tabel 2. Media Digital dan Tipe Kreativitas

\begin{tabular}{lll}
\hline \multicolumn{1}{c}{ Penggunaan Media Digital } & \multicolumn{1}{c}{ Proses Kreatif } & \multicolumn{1}{c}{$\begin{array}{c}\text { Sub Tipe } \\
\text { Kreativitas Model } \\
\text { Sternberg (2006) }\end{array}$} \\
\hline \hline $\begin{array}{l}\text { Pembelajaran pengembangan } \\
\text { produk melalui media internet }\end{array}$ & $\begin{array}{l}\text { Mengembangkan cara } \\
\text { membudidayakan sesuatu dengan } \\
\text { cara meniru proses. }\end{array}$ & Tipe replikasi \\
\hline Penelusuran disain produk pesaing & $\begin{array}{l}\text { Mencari inspirasi produk baru atau } \\
\text { alternatif disain produk lama. } \\
\text { Mencari inspirasi produk baru atau } \\
\text { alternatif disain produk lama. }\end{array}$ & $\begin{array}{l}\text { Tipe peningkatan ke } \\
\text { depan }\end{array}$ \\
& $\begin{array}{l}\text { Mencar inspirasi produk lama } \\
\text { berbahan dasar baru. }\end{array}$ & \\
\hline $\begin{array}{l}\text { Pemasaran produk melalui } \\
\text { identifikasi nama produk pesaing }\end{array}$ & $\begin{array}{l}\text { Mencari keunikan nama dagang lokal } \\
\text { untuk menarik konsumen }\end{array}$ & Tipe pengubah arah \\
\hline $\begin{array}{l}\text { Pemasaran menggunakan internet } \\
\text { online }\end{array}$ & $\begin{array}{l}\text { Memberi kemudahan konsumen } \\
\text { Pemasaran online dengan dipadu } \\
\text { model tradisional }\end{array}$ & $\begin{array}{l}\text { Memberi alternatif media baru } \\
\text { generasi milineal dan dipadukan } \\
\text { dengan tetap mempertahankan }\end{array}$ \\
& $\begin{array}{l}\text { pelanggan tradisional dengan model } \\
\text { penjualan langsung }\end{array}$ & \\
\hline
\end{tabular}

Sumber: Analisis penulis berdasarkan model Sternberg (2006)

Berdasarkan penelitian ini dapat diketahui bahwa di era digital kemampuan berkreasi sangat dibutuhkan, sehingga dapat mewujudkan inovasi sesuai bidang usaha dengan memanfaatkan media digital. Akan tetapi kreativitas perlu dipadukan dengan kemampuan menguasai pengetahuan bisnis dan kemampuan penggunaan teknologi informasi terkini. Langkah ini perlu diberikan agar memberi efek mendorong keberanian tenant untuk mengambil peluang bisnis. Keterbatasan produksi masih menjadi hambatan tenant yang belum memiliki keberanian untuk meningkatkan kapasitas produksinya dengan alasan takut rugi sehingga membatasi kapasitas produksinya. Walaupun disadari juga bahwa tidak semua bidang usaha perlu dan dapat dijalankan dengan memanfaatkan teknologi informasi, namun agar bisnis dapat selalu berkembang, maka kajian bisnis sejenis berbasis IT harus dilakukan untuk mendapatkan gambaran iklim bisnis dalam bidang usahanya. Oleh karena itu pada era 
diskrupsi digital yang terjadi saat ini, model inkubator bisnis yang telah dikembangkan di Universitas Atma Jaya Yogyakarta selama ini (Gambar 1) perlu menekankan dua hal utama yaitu soft skill dengan prioritas pada kemampuan kreativitas dan kemampuan penggunaan teknologi informasi untuk mendukung peningkatan kreativitas sehingga mendorong kemampuan berbisnis.

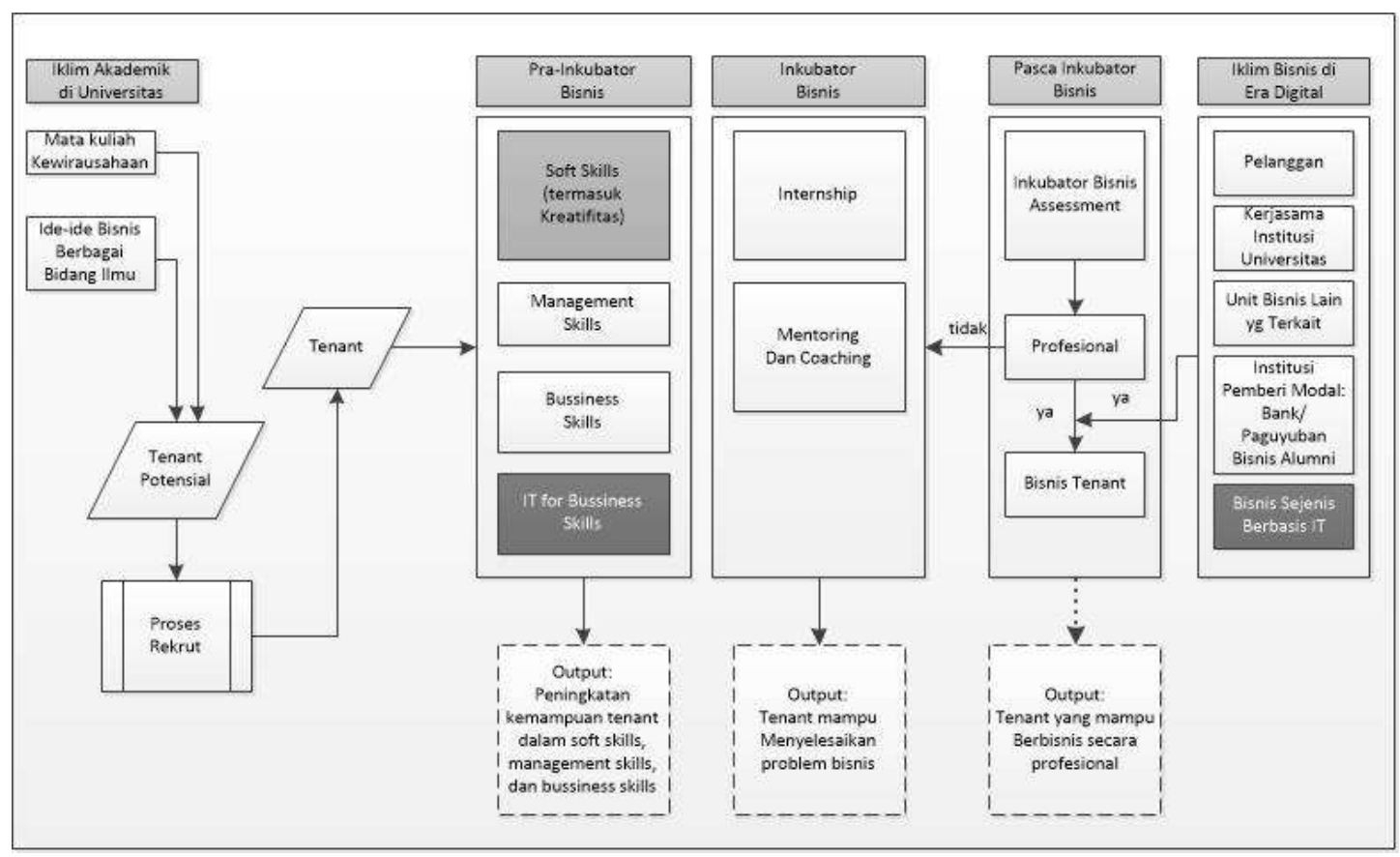

Sumber: modifikasi dari (Purwaningsih, Herawati, Pudianti, \& Septiari, 2017)

Gambar 1. Model Kewirausahaan Mahasiswa melalui Inkubator Bisnis di Era Digital

Materi kreatifitas merupakan salah satu materi yang berada di dalam materi soft skills. Materi soft skills ini diberikan pada pra inkubator bisnis, namun pada kenyataannya proses kreatif berkembang setelah para tenant mengalami berbagai tantangan saat telah masuk ke dalam iklim bisnis dan mereka akan kembali mengolah ide-ide baru melalui dengan menggunakan tipe dan sub tipe kreativitas yang semakin meningkat.

\section{KESIMPULAN}

Era digital merupakan era baru yang jika ditanggapi sebagai sebuah tantangan akan menghasilkan kreativitas baru. Pada model inkubator bisnis di Universitas Atma Jaya Yogyakarta yang berupaya membentuk wirausaha pemula ini terdapat tiga pilar kreativitas yaitu pilar pertama tipe kreativitas yang menerima paradigma masa kini dengan upaya, pilar ke dua tipe kreativitas yang menolak paradigma saat ini dan 
berupaya menggantikan posisi, dan pilar ke tiga yaitu tipe kreativitas yang mensintesakan paradigma saat ini. Akan tetapi dari tiga pilar tersebut hanya ada empat sub tipe yang dapat diidentifikasi dalam kurun waktu tiga tahun pelaksanaan yaitu sub tipe replikasi, sub tipe peningkatan ke depan, sub tipe pengubah arah dan sub tipe integrasi. Untuk tahap wirausaha pemula, keempat sub tipe tersebut merupakan permulaan yang cukup baik dan perlu dikenalkan dan dikembangkan sub tipe lain melalui modul pembekalan inkubator bisnis agar memberi wawasan yang lebih luas bagi calon wirausaha pemula.

Model Kewirausahaan Mahasiswa melalui Inkubator Bisnis telah mengintegrasikan berbagai aspek dalam setiap tahap inkubator bisnis secara berkesinambungan, akan tetapi model ini sangat terbatas karena disusun secara dua dimensi. Pada kenyataannya materi dalam setiap tahap tidak berjalan secara linier akan tetapi berjalan secara spiral. Pada tahap pra inkubator bisnis pengetahuan dan kemampuan dasar wirausaha tidak hanya didapatkan dari materi yang disampaikan akan tetapi bersinergi dengan pengetahuan bawaan setiap calon wirausaha. Setiap calon wirausaha mandiri memiliki pengalaman berbeda yang akan lebih efektif diolah melalui tahap inkubator bisnis yaitu melalui tahap mentoring dan coaching. Praktek kreativitas dipadu penguasaan media digital sangat efektif dilakukan pada tahap ini mengingat perbedaan pengalaman dan latar belakang tenant.

Berdasarkan keterbatasan penelitian ini, maka akan sangat disarankan pada penelitian yang akan datang mengembangkan model lebih detil khususnya pada tahap kedua yaitu inkubator bisnis melalui proses mentoring dan coaching untuk mengetahui proses kreatif yang terjadi dengan intervensi diskrupsi digital dengan memasukkan variabel waktu sebagai variabel kontrol dengan tujuan melihat kemampuan adaptasi wirausaha di era digital.

\section{REFERENSI}

Baldacchino, L. (2009). Entepreuneurial Creatifity and Innovation. First International Conference on Strategic Innovation and Future Creation, (pp. 1-15). Floriana, Malta.

Hardiyati, E. (2011, Maret). Kreatifitas dan Inovasi Berpengaruh Terhadap Kewirausahaan Usaha Kecil. Jurnal Manajemen dan Kewirausahaan, 13(No. 1), 8-16.

Herawati, A. F., Purwaningsih, A., \& Pudianti, A. (2015). Ipteks bagi Kewirausahaan (IbK) di Universitas Atma Jaya Yogakarta. Yogyakarta: LPPM Universitas Atma Jaya.

Herawati, F. A., Purwaningsih, A., \& Pudianti, A. (2016). Ipteks bagi Kewitausahaan (IbK) Tahun Ke dua. Yogyakarta: LPPM Universitas Atma Jaya Yogyakarta. 
Herawati, F. A., Purwaningsih, A., \& Pudianti, A. (2017). Ipteks bagi Kewirausahaan (IbK) tahun ke tiga. Yogyakarta: LPPM Universitas Atma Jaya Yogyakarta.

Herawati, F. A., Septiari, E. D., Purwaninsgih, A., \& Pudianti, A. (2016). Mendukung Mahasisa Berwirausaha Melalui Pendekatan Inkubator Bisnis. Seminar Nasional Kewirausahaan \& Inovasi Bisnis VI (pp. 204-212). Jakarta: Universitas Tarumanagara .

Hizam, S. B., \& Khairuddin, H. (2015). Occupational Strees Among Entepreneurs in Malaysian SMEs: A Concentual Framework. Review of Integrative Business \& Economics Research, 53-60.

Kasali, R. (2017). Discruption. Jakarta: Gramedia.

Kementrian Koperasi dan Usaha Kecil dan Menengah Republik Indonesia. (2017, Januari 23). Layanan Informasi Bantuan Pemerintah bagi Koperasi dan Wirausaha Pemula. Jakarta, DKI Jakarta. http://www.depkop.go.id/layananpublik/wirausaha-pemula-wp/ diunduh 16 September 2017

Lubart, T.I. (2001). Models of the Creative Process: Past, Present and Future. Creativity Research Journal. Volume 13, 2001 - Issue 3-4, 295-308.

Murwaningsih, T. (2015). Model Pengembangan Program Wirausaha Mahasiswa Integratif di Universitas Sebelas Maret. Seminar Nasional 4 UNS SME's Summit \& Awards, Sinergitas Pengembangan UMKM dalam Era Masyarakat Ekonomi ASEAN (MEA), (pp. 240-248). Surakarta.

Pramdia Arhando Julianto, Artikel ini telah tayang di Kompas.com dengan judul "2017, Pemerintah Target Ciptakan 5.000 Wirausaha Baru", https://ekonomi.kompas.com/read/2017/03/05/080000226/2017.pemerintah.targ et.ciptakan.5.000.wirausaha.baru\%20diunduh\%2016\%20September\%202017.

Purwaningsih, A., Herawati, A., Pudianti, A., \& Septiari, E. D. (2017, April). Crafting a Model of Student Entrepreneurs through Business Incubators. Review of Integrative Business and Economics Research, 6(2), 312-325.

Sternberg. R.J. (2006). The Nature of Creativity, Creativity Research Journal. Volume 18 No 1. 87-98.

Yin, R. K. (2013). Studi Kasus: Disain dan Metode. Terjemahan Case Study Reseach: Design and Methods. Jakarta: Raja Grafindo Persada. 